Isolation and identification of thermophilic and mesophylic proteolytic bacteria from shrimp paste "Terasi"

R. Murwani', Supriyadi' , Subagio, A. Trianto', and Ambariyanto'

Citation: 1699, 030005 (2015); doi: 10.1063/1.4938290

View online: http://dx.doi.org/10.1063/1.4938290

View Table of Contents: http://aip.scitation.org/toc/apc/1699/1

Published by the American Institute of Physics 


\title{
Isolation and Identification of Thermophilic and Mesophylic Proteolytic Bacteria from Shrimp Paste "Terasi"
}

\author{
R. Murwani ${ }^{1,3, \mathrm{a}^{*}}$, Supriyadi ${ }^{2, \mathrm{~b}}$, Subagio $^{2}$, A.Trianto ${ }^{1,2, \mathrm{c}}$, Ambariyanto $^{1,2, \mathrm{~d}}$ \\ ${ }^{1}$ Natural Product Laboratory, Centre of Research and Services (Laboratorium Terpadu) \\ ${ }^{2}$ Department of Marine Science, Faculty of Fisheries and Marine Science, \\ ${ }^{3}$ Faculty of Animal Science and Agriculture, Diponegoro University, Semarang Indonesia \\ ${ }^{\left.a^{*}\right)}$ Corresponding author: retnomurwani@ymail.com \\ b) supriyadi0108@dexa-medica.com \\ c) triantotelurawur@gmial.com \\ d) ambariyanto.undip@gmail.com
}

\begin{abstract}
Terasi is a traditional product generally made of fermented shrimp. There were many studies regarding lactic acid bacteria of terasi but none regarding proteolitic bacteria. This study was conducted to isolate and identify the thermophilic and mesophylic proteolytic bacteria from terasi. In addition, the effect of different salt concentrations on the growth of the isolated proteolytic bacteria with the greatest proteolytic activity was also studied. Terasi samples were obtained from the Northern coast region of Java island i.e. Jepara, Demak and Batang. The study obtained 34 proteolytic isolates. Four isolates were identified as Sulfidobacillus, three isolates as Vibrio / Alkaligenes / Aeromonas, two isolates as Pseudomonas, 21 isolates as Bacillus, three isolates as Kurthia/ Caryophanon and one isolates as Amphibacillus. The growth of proteolytic bacteria was affected by salt concentration. The largest growth was found at $0 \mathrm{ppm}$ salt concentrations and growth was declined as salt concentration increased. Maximum growth at each salt concentration tested was found at 8 hours incubation.
\end{abstract}

Keywords : Terasi, fermented shrimp, thermophylic, mesophylic, proteolitic bacteria, halotolerant

\section{INTRODUCTION}

Terasi or shrimp paste was made traditionally from shrimp, however fish can also be used. The shrimp was washed, sun dried, pounded and kept indoor to let fermentation take place. After alternate drying, pounding, and kept in door the product was molded and wrapped to let further fermentation take place. It has been used for century as a flavoring ingredient by Indonesian people. However, similar product is common in Southeast Asian (Thailand, Malaysia, Burma, Cambodia, Philipine, Myanmar, and Vietnam) [1]. Fermentation of Terasi was carried out by endogenous enzymes derived from shrimp and their microorganisms. As shrimp is a substrate rich of protein it is natural that proteolitic bacteria play roles during the fermentation of terasi. Proteolitic activity leads to protein hydrolysis which produced various chemicals such as peptide and amino acids with antioxidant properties and umami taste respectively [2]. Fermentation also produced volatile aromas typical of Terasi [3]. While lactic acid bacteria from Terasi have been well studied by many [4,5,6,7] proteolytic bacterial study is scarce. Therefore the present study was undertaken to isolate and identify the proteolytic bacteria of Terasi samples obtained from the Northern coast of Central Java namely Jepara, Demak and Batang. 


\section{MATERIALS AND METHODS}

\section{Materials}

Terasi samples were obtained from the northern coast of Central Java i.e Jepara, Demak and Batang. Terasi in this regions is traditionally made of small shrimps. The three regions have their own raw materials to make Terasi. Calsium Caseinate Agar were used for isolation and maintenance of proteolytic bacteria. Oxidation Fermentation $(\mathrm{O} / \mathrm{F})$ Medium was used for glucose fermentation and motility test, Lactose Broth (LB) Medium for lactose fermentation test, Nutrient Broth with added glucose was used for acid formation test, and Nutrien Broth (NB) with Hydrolyzed Casein were used for indol test [8].

\section{Sampling Methods}

Sampling of terasi was done randomly from terasi production area i.e Northern Coast of Central Java i.e Jepara, Demak and Batang from traditional producer (blue dots on the map below).

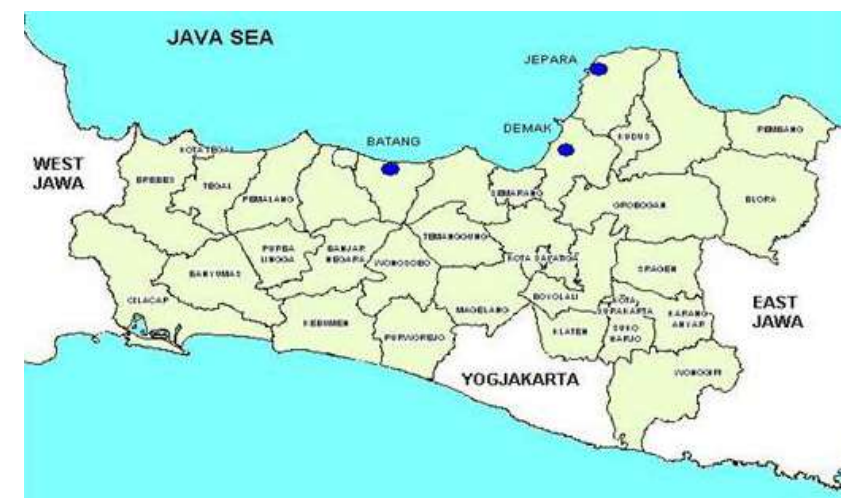

Figure 1. Map of Terasi sampling regions (๑)

\section{Calcium Caseinate Agar (CCA) Preparation}

Calcium caseinates agar was made of $5 \mathrm{~g}$ peptone, $3 \mathrm{~g}$ meat extract, $2.5 \mathrm{~g}$ casein Hammarstein, $5 \mathrm{~g} \mathrm{NaCl}, 0.15 \mathrm{~g} \mathrm{Ca}$ $(\mathrm{OH})_{2}, 0.05 \mathrm{~g} \mathrm{CaCl}_{2}$ and $15 \mathrm{~g}$ agar. $500 \mathrm{ml}$ aquadest was added to the mixture and heated. $20 \mathrm{~g}$ skim milk powder was dissolved in $500 \mathrm{ml}$ aquadest. The two solutions were then mixed [8].

\section{Isolation of thermophilic and mesophylic proteolytic bacteria}

Isolation of thermophilic and mesophyllic proteolytic bacteria were carried out by pour plate method [8, 9, 10] on CCA using $1 \mathrm{~g}$ of terasi sample. Incubation was carried out for 24 hours at two different temperatures i.e. $30{ }^{\circ} \mathrm{C}$ to obtain mesophylic bacteria and $50{ }^{0} \mathrm{C}$ to obtain thermophilic bacteria. Proteolytic bacteria was identified by the presence of clear zone on CCA.

\section{Identification of thermophilic and mesophylic proteolytic bacteria}

Identification of bacteria were based on Bergey's Manual of Determinative Bacteriology [11] which covers morphological observations and biochemical test. Morphological observations consisted of colony color and surface appearance, bacterial shape, gram staining, endospore staining, and bacterial motility test. Biochemical tests include glucose and lactose fermentation $(\mathrm{O} / \mathrm{F})$, acid-fast staining, catalase and indole tests. 


\section{Determination of the Growth of Proteolytic Bacteria in the Presence of Salt}

Selection of bacteria was made on the basis of the size of clear zone around the colony. Bacteria that had the largest clear zone diameter are the ones with the greatest proteolytic activity. They were tested for growth kinetics at various salt concentrations. Bacterial growth was carried out on selected isolates by turbidimetry $[9,10,12]$. In this test, the bacteria was grown in Liquid Skim Milk (half strength) culture with various salt concentration (0 ppm, 15 ppm, $30 \mathrm{ppm}$ and $45 \mathrm{ppm}$ ) in a total of $50 \mathrm{ml}$ volume.

Three $\mathrm{ml}$ samples were taken and put into centrifuge tubes and spinned for 15 minutes at $3000 \mathrm{rpm}$. Pellets were washed twice with $3 \mathrm{ml}$ of physiological salt. Turbidity value is measured by a spectrophotometer at $500 \mathrm{~nm}$. Samples were taken at intervals of $0.5,1,2,4,8,16,32$ hour incubation.

\section{RESULTS \& DISCUSSION}

\section{Isolation of proteolytic bacteria}

The result of total number of proteolytic thermophilic and mesophylic bacteria from different regions of northern coast of Central Java was shown in Table 1.

Table 1.The average number of proteolytic thermophylic $\left(50^{\circ} \mathrm{C}\right)$ and mesophylic $\left(30^{\circ} \mathrm{C}\right)$ bacteria in terasi

\begin{tabular}{ccc}
\hline Bacterial Types & Origin of terasi & Total proteolytic bacteria (CFU / g) \\
\hline Thermophilic & Jepara & $3,1 \times 10^{4}$ \\
& Demak & $6,1 \times 10^{4}$ \\
& Batang & $1,6 \times 10^{5}$ \\
Mesophylic & Jepara & $1,1 \times 10^{4}$ \\
& Demak & $1,0 \times 10^{4}$ \\
& Batang & $4,5 \times 10^{4}$ \\
\hline
\end{tabular}

Table 2. Diameter of clear zone isolate

\begin{tabular}{cccc}
\hline Isolate & $\begin{array}{c}\text { Clear zone diameter } \\
(\mathrm{cm})\end{array}$ & Isolate & $\begin{array}{c}\text { Clear zone diameter } \\
(\mathrm{cm})\end{array}$ \\
\hline DM-1 & 1,5 & JT-1 & 1,4 \\
DM-2 & 0,4 & JT-2 & 1,8 \\
DM-3 & 1,2 & JT-3 & 1,6 \\
DM-4 & 0,9 & JT-4 & 1,8 \\
DM-5 & $\underline{1,8}$ & JT-5 & 0,9 \\
DM-6 & 0,8 & JT-6 & $\underline{\mathbf{2 , 4}}$ \\
DT-1 & 0,9 & JT-7 & 0,9 \\
DT-2 & 1,7 & BM-1 & $\underline{2,3}$ \\
DT-3 & 0,6 & BM-2 & 0,9 \\
DT-4 & 0,8 & BM-3 & 0,7 \\
DT-5 & $\underline{1,8}$ & BM-4 & 1,2 \\
JM-1 & 1,0 & BM-5 & 1,7 \\
JM-2 & $\underline{\mathbf{2 , 8}}$ & BT-1 & $\underline{2,0}$ \\
JM-3 & 1,5 & BT-2 & 0,9 \\
JM-4 & 1,7 & BT-3 & 1,1 \\
JM-5 & 1,8 & BT-4 & 1,2 \\
JM-6 & 2,2 & BT-5 & 0,3 \\
\hline
\end{tabular}

D: Demak, J: Jepara, B: Batang, M: mesophyllic proteolytic bacterial isolates, T: thermophilic proteolytic bacteria, $1,2,3,4,5,6,7$ : isolate number, *: isolate with the largest clear zone to be used for study of salt concentration effect on bacterial growth. 
The largest number of proteolytic thermophylic bacteria was found in samples from Batang $\left(1,6 \times 10^{5} \mathrm{CFU} / \mathrm{g}\right)$ and the lowest one was found in samples from Jepara. Similar result was found for proteolytic mesophylic bacteria i.e the largest number was found from Batang. Greater proteolytic bacterial number was most likely to be due to the protein content of the raw material used in Batang was greater than from other region. This is in line with the result of volatile compounds of nitrogen group (chromatogram peak area) from Batang was greater than Jepara and Demak [3]. The number of proteolytic bacteria which was larger than mesophylic bacteria was likely due to the intensity of sun drying. The more sun drying was employed the more thermophylic bacteria would grow.

Isolation of proteolytic bacteria (thermophilic and mesophylic) produced 34 isolates. The 34 isolates and their proteolytic activity on the basis of casein break down were shown in Table 2. The greatest proteolytic activity for thermophylic and mesophylic bacteria was found in Terasi from Jepara with clear zone diameter of $2.4 \mathrm{~cm}$ (JT-6) and $2.4 \mathrm{~cm}$ (JM-2) respectively (bold and underlined). In general the clear zone diameter of mesophylic bacteria was greater than thermophylic bacteria in the three regions (underlined). It indicated that the greatest proteolytic activity occured when terasi being kept indoor when fermentation taking place not during sun drying. Enzymatic activity is more stable at temperature below $45^{\circ} \mathrm{C}$ and greatly reduced above $50^{\circ} \mathrm{C}$ depending on the enzyme.

\section{Identification of Proteolytic Bacteria}

The colony morphological observation of 34 mesophyllic and thermophilic isolates were shown in Table 3, whereas the morphological properties and biochemistry of the 34 isolates were shown in Table 4 .

Table 3. Morphological colony observation of proteolytic isolates

\begin{tabular}{clllll}
\hline $\begin{array}{c}\text { Code of } \\
\text { isolates }\end{array}$ & \multicolumn{1}{c}{ Color } & \multicolumn{1}{c}{$\begin{array}{c}\text { Surface } \\
\text { Appearance }\end{array}$} & $\begin{array}{c}\text { Code of } \\
\text { isolates }\end{array}$ & \multicolumn{1}{c}{ Color } & \multicolumn{1}{c}{$\begin{array}{c}\text { Surface } \\
\text { appearance }\end{array}$} \\
\hline DM-1 & White & Dampish & JT-1 & White & Dampish \\
DM-2 & White & Rather dry & JT-2 & White & Dampish \\
DM-3 & White & Dampish & JT-3 & White & Dampish \\
DM-4 & Reddish white & Dampish & JT-4 & Yellowish white & Dampish \\
DM-5 & White & Dampish & JT-5 & Yellowish white & Dampish \\
DM-6 & White & Dampish & JT-6 & White & Rather dry \\
DT-1 & yellowish white & Dampish & JT-7 & White & Rather dry \\
DT-2 & yellowish white & Dampish & BM-1 & Cream & Dampish \\
DT-3 & White & Dampish & BM-2 & Yellowish white & Rather dry \\
DT-4 & White & Dampish & BM-3 & White & Rather dry \\
DT-5 & yellowish white & Dampish & BM-4 & White & Dampish \\
JM-1 & yellowish white & Dampish & BM-5 & White & Dampish \\
JM-2 & Reddish white & Dampish & BT-1 & White & Rather dry \\
JM-3 & White & Rather dry & BT-2 & Cream & Dampish \\
JM-4 & Yellowish white & Rather dry & BT-3 & Yellowish white & Dampish \\
JM-5 & White & Dampish & BT-4 & White & Dampish \\
JM-6 & white & Dampish & BT-5 & white & Dampish \\
\hline
\end{tabular}

D: Demak, J: Jepara, B: Batang, M: mesophyllic proteolytic bacterial isolates,

$\mathrm{T}$ : thermophilic proteolytic bacteria, $1,2,3,4,5,6,7$ : isolate number 
Table 3 showed that some of the isolates produced colour which was due to pigmen synthesized by the bacteria. Bacterial pigmen can be classified into carotenoid, anthocyanin, melanin, tripirilmethnes, and phenazin. Carotenoid colours are ranged from red, orange, to yellow. Anthocyanin are red and blue, melanin are brown, black, orange, and red. Tripirilmethenes are red while phenazin orange-yellow.

Table 4 showed the characteristics of proteolitic bacterial isolates obtained in Table 3. On the basis of these characteristics the identification of thermophilic proteolytic bacteria of terasi from Demak showed that five isolates belong to the genus Bacillus. On the other hand, the mesophyllic proteolytic bacteria from the same place showed that three isolates belong to Sulfidobacillus (Figure 2a), one isolate as Bacillus (Figure 2b), one isolates as Kurthia / Caryophanon, and one isolate as Amphibacillus. Thermophilic, proteolytic bacteria of Terasi from Batang showed that one isolate belong to the genus of Vibrio / Alkaligenes / Aeromonas, and four isolates as Bacillus. The mesophyllic proteolytic bacteria from the same place showed that two isolates belong to Pseudomonas and three isolates as Bacillus. Thermophilic, proteolytic bacteria of Terasi from Jepara showed that one isolate belong to Vibrio / Alkaligenes / Aeromonas and six isolates as Bacillus. The mesophyllic proteolytic bacteria from Jepara showed that one isolates belong to Sulfidobacillus, one isolate as Vibrio / Alkaligenes / Aeromonas, two isolates as Bacillus, and two isolates as Kurthia / Caryophanon.

Table 4. Characteristics of the proteolytic bacterial isolates by morphology and biochemical test

\begin{tabular}{|c|c|c|c|c|c|c|}
\hline Characteristics & Results & & & & & \\
\hline Cell shape & rod & rod & rod & rod & rod & rod \\
\hline Gram staining & $(+)$ & $(-)$ & $(-)$ & $(+)$ & $(+)$ & $(+)$ \\
\hline Catalase test & $(+)$ & $(+)$ & $(+)$ & $(+)$ & $(+)$ & $(-)$ \\
\hline Motility test & $(-)$ & $(+)$ & $(-)$ & $(+)$ & $(+)$ & $(+)$ \\
\hline Test $\mathrm{O} / \mathrm{F}$ & $(+)$ & $(+)$ & $(+)$ & $(+)$ & $(+)$ & $(+)$ \\
\hline \multicolumn{7}{|c|}{ Formation of acid from: } \\
\hline 1. glucose & $(+)$ & $(+)$ & $(+)$ & $(+)$ & $(+)$ & $(+)$ \\
\hline 2. lactose & $(-)$ & $(-)$ & $(-)$ & $(-)$ & $(-)$ & $(-)$ \\
\hline Indole test & $(-)$ & $(-)$ & $(-)$ & $(-)$ & $(-)$ & $(-)$ \\
\hline Spores & $(+)$ & $(+)$ & $(+)$ & $(+)$ & $(-)$ & $(+)$ \\
\hline staining & $(-)$ & $(-)$ & $(-)$ & $(-)$ & $(-)$ & $(+)$ \\
\hline \multicolumn{7}{|l|}{ Acid staining } \\
\hline Genus & $\begin{array}{l}\text { Sulfidobacillus } \\
\text { (Figure 2a) }\end{array}$ & $\begin{array}{c}\text { Vibrio/ } \\
\text { Alkaligenesel } \\
\text { Aeromonas }\end{array}$ & Pseudomonas & $\begin{array}{c}\text { Bacillus } \\
\text { (Figure 2b) }\end{array}$ & $\begin{array}{l}\text { Kurthial } \\
\text { Caryophanon }\end{array}$ & $\begin{array}{c}\text { Amphib } \\
\text { acillus }\end{array}$ \\
\hline \multirow[t]{11}{*}{ Isolate number } & DM-1, DM-3 & JM-3, JT-4 & BM-2, BM-4 & JM-5, JM-6 & JM-1, JM-4 & DM-2 \\
\hline & DM-6, JM-2 & BT-3 & & JT-1, JT-2 & DM-4 & \\
\hline & & & & JT-3, JT-5 & & \\
\hline & & & & JT-6, JT-7 & & \\
\hline & & & & BM-1, BM-3 & & \\
\hline & & & & BM-5, BT-1 & & \\
\hline & & & & BT-2, ВT-4 & & \\
\hline & & & & BT-5, DM-5 & & \\
\hline & & & & DT-1, DT-2 & & \\
\hline & & & & DT-3, DT-4 & & \\
\hline & & & & DT-5 & & \\
\hline
\end{tabular}

D: Demak, J: Jepara, B: Batang, M: mesophyllic proteolytic bacterial isolates,

$\mathrm{T}$ : thermophilic proteolytic bacteria, 1,2,3, 4,5,6,7 : isolate number 

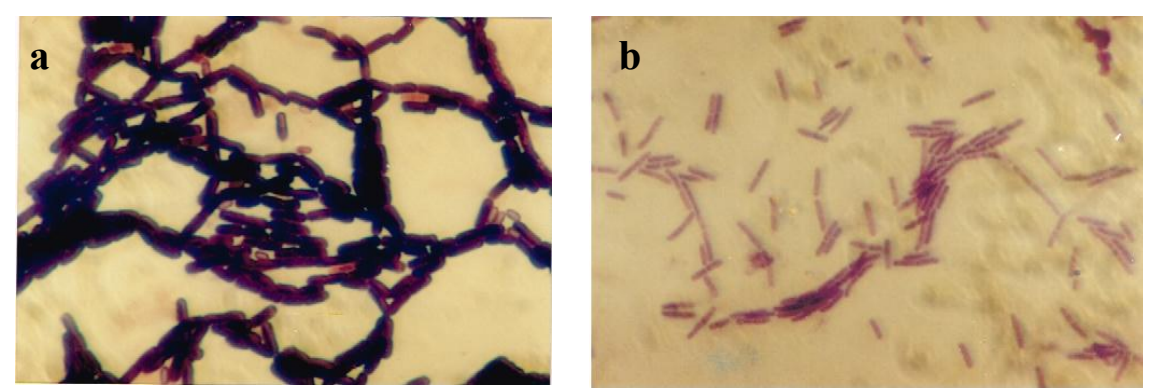

Figure 2. Examples of the gram staining of the bacterial isolates a) Sulfidobacillus, b) Bacillus

This study showed that the genus Bacillus were the most numerous in terasi, followed by Sulfidobacillus, Vibrio /Alkaligenes /Aeromonas, Kurthia /Caryophanon, Pseudomonas, and Amphibacillus. Bacillus is a rod-shaped grampositive bacteria found single, in pairs, or forming chains. They are aerobic or facultative anaerobes which have the ability to stand heat, $\mathrm{pH}$ and salinity [11]. These results were different than that by [13] who showed that three proteolytic bacteria isolated from fish paste raw materials derived from Gresik and Sidoarjo was Micrococcus. Some of the isolates produced pigments which give them color appearance (Table3). Some of Gram-negative bacteria which produce red pigments are few species of Pseudomonas and Serratia [14]. It is also interesting to note that no acid was formed in lactose fermentation test which indicative of the absence of E.coli. Although indole test was negatif for all isolates, indole as volatile compound was identified in terasi from the three regions [3]. Indole in trace amount can give depth to the existing aroma of terasi.

\section{Bacterial Growth in The Presence of Salt}

On the basis of Table 2, JM-2 was chosen as the isolate with the strongest proteolytic activity (largest clear zone) and tested further for growth in the presence of salt. Bacterial growth is shown in Figure 3 where the largest growth was found at $0 \mathrm{ppm}$ salt concentrations. The growth decreased as salt concentration increased. The same pattern of growth was found at $15 \mathrm{ppm}$ salt concentration. At 0 and $15 \mathrm{ppm}$ salt concentration, the proteolytic bacterial growth increased up to 8 hours after which it declined. At higher salt concentration i.e. 30 and 45 ppm the bacterial growth also increased up to 16 hours after which it declined.

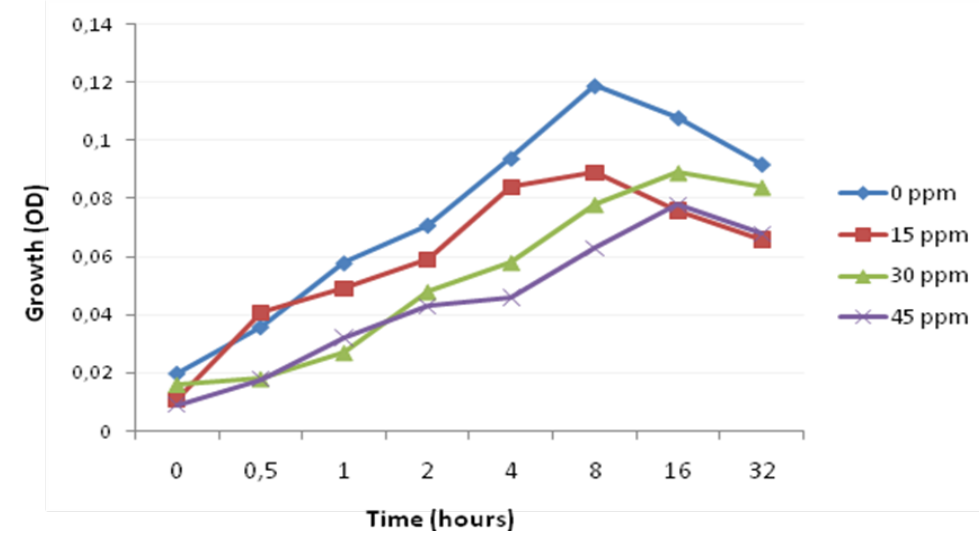

Figure 3. Growth curve of bacteria at different salt concentration

High salt concentrations can inhibit bacterial growth. Salt absorbs water from bacterial cells, causing cell lysis due to high osmotic pressure. Salt can also found in ionized form i.e $\mathrm{Cl}^{-}$which are harmful to bacteria causing protein to be less soluble. As the greatest proteolytic bacterial growth was found at $0 \mathrm{ppm}$ salt concentration and that the 
bacteria were still growing at higher salt concentration up to $45 \mathrm{pppm}$ indicated that the isolates were halotolerant. These bacteria can grow in the absence or presence of salt and therefore Terasi making can use salt or no salt. These results were in line with that by [14] who found halotolerant and medium-halophilic bateria in Belachan from Bogor. She showed that the highest salt concentration tolerated by the bacteria isolated from Belachan was 15-20\% which was lower than this study.

\section{CONCLUSION}

Thermophilic and mesophllic proteolytic bacteria of Terasi from Jepara, Demak and Batang produced 34 isolates and they belong to the genus Sulfidobacillus, Vibrio /Alkaligenes/ Aeromonas, Kurthia /Caryophanon, Pseudomonas, Bacillus and Amphibacillus. Further identification by molecular techniques should be carried out to identify the species of the isolates. Pigment production by the isolates should be further studied in relation to natural colouring of Terasi.

\section{REFERENCES}

1. P. Hajeb and S. Jinap, Journal of Nutrition and Food Science doi:10.4172/2155-9600, S10-006 (2012).

2. J. Pongsetkul, S. Benjakul, P. Sampavapol, K. Osako, and N. Faithong, International Food Research Journal, 22(4), 1454-1465 (2015).

3. R. Murwani, H. S. A Putra., H. Widiyanto, A.Trianto, Ambariyanto. 2nd International Symposium on Aquatic Products Processing and Health, ISAPPROSH 13-15 September. Diponegoro University (2015).

4. I.S. Surono and A. Hosono, Journal of Food Hygience Society Japan, 35(3), 299-304 (1994).

5. T. Kobayashi, M. Kajiwara, M. Wahyuni, N. Hamada-Sato, C. Imada, and E. Watanabe, Journal of Applied Microbiology, 96, 1215-1221 (2004).

6. T. Kobayashi, M. Kajiwara, M. Wahyuni, T. Kitakado N. Hamada-Sato, C. Imada, and E. Watanabe, Journal of General Applied Microbiology, 49, 279-286 (2003).

7. C. Sanchart, S. Benjakul, O. Rattanaporn, D. Haltrich, and S. Maneerat, Songklanakarin Journal of Science and Technology, 37(3), 291-297 (2015).

8. R. Pudyastuti, Thesis. FTP Gadjah Mada University. Yogyakarta. 33 pp. (2000).

9. B. W. Lay, Raja Grafindo Persada. Jakarta. 168 pp. (1994).

10. S. Fardiaz. Department of Food Technology and Nutrition, FATETA, IPB. Bogor (1982).

11. J.G. Holt, N.R. Krieg, P.H.A. Sneath, J.T. Stanley, S.T. William, The William \& Wikins Co., USA, 786 pp. (1994).

12. G. Sa'id, Mediyatama Sarana Perkasa. Jakarta. 318 pp. (1987).

13. T. M. Setyowati, Thesis. Graduate Program, University of Gadjah Mada. Yogyakarta, 86 pp.

14. R. F. R. Susilowati, Thesis. Fateta IPB. Bogor. (1988). 